Article

\title{
Upscaling the Zeolite-Anammox Process: Treatment of Anaerobic Digester Filtrate
}

\author{
Robert S. Collison and Mark E. Grismer *(1) \\ Biological \& Agricultural Engineering, University of California Davis, Davis, CA 95616, USA; \\ rscollison@ucdavis.edu \\ * Correspondence: megrismer@ucdavis.edu; Tel.: +1-530-304-5797
}

Received: 20 September 2018; Accepted: 30 October 2018; Published: 1 November 2018

\begin{abstract}
State regulatory and other agencies identified that nitrogen loading from the wastewater treatment plants (WWTPs) discharging around its periphery has adversely affected the San Francisco Bay (SFB) water quality. Here we consider the upscaling of the zeolite-anammox process treatment to nitrogen removal from relatively high-ammonia content $\left(\sim 500 \mathrm{NH}_{3}-\mathrm{N} \mathrm{mg} / \mathrm{L}\right)$ anaerobic-digester (AD) filtrate to facilitate reductions in WWTP nitrogen discharge. First, by operating a $210 \mathrm{~L}$ barrel reactor as a trickling filter with a $10 \%$ by volume initial bio-zeolite seeding fraction, we found that 6-8 weeks elapsed before the anammox activity became apparent. Moreover, the 10-mm zeolite aggregate reactor achieved an $89 \%$ ammonia-N removal compared to the $85 \%$ achieved by the $20-\mathrm{mm}$ aggregate. We then evaluated the performance of the trickling-filter design in a $68 \mathrm{~m}^{3}$ Baker tank nearly filled with 20-mm zeolite aggregate seeded with bio-zeolite at about $1.5 \%$ by volume. At an average inflow of $42 \mathrm{~m}^{3} /$ day, about one year elapsed before achieving adequate anammox activity and acceptable treatment. Unfortunately, inadequate suspended solids pre-treatment of the $\mathrm{AD}$ filtrate resulted in clogging problems in the Baker tank reactor, so we evaluated aerobic-anaerobic cycling within the tank and then operated it (anaerobically) as a nitrate-scavenging tank. In the final anaerobic operational stage, nitrate effluent concentrations were $<1 \mathrm{mg} / \mathrm{L}$, perhaps due to dissimilatory nitrate reduction to ammonium by the anammox process, but ammonia removal fractions were only about $47 \%$.
\end{abstract}

Keywords: wastewater treatment; anammox bacteria; nitrification; zeolite; anaerobic digester filtrate

\section{Introduction}

As discussed in a companion paper (Collison and Grismer [1]), San Francisco Bay (SFB) estuary water quality is adversely affected by nitrogen loading from wastewater treatment plant (WWTP) discharges on the Bay periphery (SFEI [2]). As such, there is an increasing regulatory scrutiny of WWTP nitrogen discharges intensifying WWTP interest in developing cost-effective methods to reduce nitrogen loading in their discharge. One method of facilitating the reduction of nitrogen concentrations or loads from WWTPs is to treat the high-ammonia content $(\sim 500 \mathrm{mg} / \mathrm{L})$ anaerobic-digester (AD) filtrate or side-stream effluent prior to its re-incorporation into the WWTP treatment train. Usually, the ammonium-rich filtrate is returned to the WWTP head works for further treatment where it can increase the ammonium loading to the WWTP treatment train by as much as $30 \%$, despite the very small contribution (1-5\%) to the total WWTP flow (Lackner et al. [3]). While ADs can produce side-streams with ammonium-N concentrations of $\sim 1000 \mathrm{mg} / \mathrm{L}$ (Dapena-Mora et al. [4]), here, we work with AD liquid 'filtrate' that was obtained from belt-press filters that de-water AD sludge and is diluted by the filter washing process. Development of low-cost treatment operations that can reduce the AD filtrate nitrogen loading to the WWTP treatment train has the potential of significantly reducing the eventual discharge of nitrogen concentrations from the WWTP. 
The zeolite-anammox system uses a symbiotic combination of nitrifying, denitrifying, and anammox bacteria that eventually convert ammonia to nitrogen gas in one reactor (Collison and Grismer $[1,5])$. Thus far, as compared to other WWTP nitrogen-removal reactors, we have found that zeolite-anammox reactors are simpler, easier, and less expensive to operate, as they require only one reactor (as compared to multi-stage systems) and do not require a supplemental organic food source, heating, or aeration. The zeolite-anammox system appears to overcome the relatively high temperature and ammonia concentrations required by anammox or partial nitritation reactors because we speculate that the zeolite immobilizes the influent ammonium ions at cation-exchange sites where the anammox bacteria can 'strip' these ions from the zeolite and, when combined with the available nitrite, eventually convert them to nitrogen gas. When maintained in anoxic conditions, some anammox strains (e.g., K. stuttgartiensis) are also capable of dissimilatory nitrate reduction to ammonium (DNRA) bypassing the ammonium-nitrite combination step (Mansell [6]; Grismer and Collison [7]).

While Collison and Grismer [5] focused on the role of zeolites in nitrogen removal from the channel reactors, Collison and Grismer [1] extended that application to nitrogen removal from secondary-treated wastewater having ammonia-N concentrations of $25-75 \mathrm{mg} / \mathrm{L}$. In both studies, they found that the zeolite-anammox reactor removed $98-99 \%$ of the influent ammonium without an apparent significant dependence on denitrification because the ammonia removal rates far exceeded the zeolite adsorption (Cation Exchange Capacity (CEC)) capacity and lack of sufficient carbon (i.e., Biological Oxygen Demand (BOD)) limited ammonia-N removal by denitrification to $<1 \mathrm{mg} / \mathrm{L}$. That is, we think that nitrifying bacteria in the zeolite biofilm approximately convert half the ammonia to nitrite using the first stage of nitrification while the adjacent anammox bacteria combine the ammonium and nitrite to form nitrogen gas. The zeolite aggregate's ability to soak up water and create an extensive aerobic/anaerobic interface (oxycline) creates favorable environmental conditions for the anammox bacteria to have access to both nitrite and ammonium. The continuous cycle of adsorption and biological removal of the ammonium ions enables the system to self-regenerate and it appears to be self-regulating, requiring minimal monitoring and adjustment.

\section{Research and Project Objectives}

While Collison and Grismer [1] explored the performance of a shallow-bed linear-channel zeolite-anammox reactor in removing ammonia from low-strength secondary-treated effluent, here, we focus on its application in removing ammonia from high-ammonium content wastewater such as AD filtrate under WWTP conditions. More specifically, we investigated the treatment performance of two zeolite aggregate sizes using three $210 \mathrm{~L}$ ( $55 \mathrm{gal}$ ) barrel trickling-filter reactors as well as the operation of a pilot-scale $68 \mathrm{~m}^{3}$ (18,000 gal) zeolite-anammox reactor under a range of aeration conditions during a 22-month period. The barrel reactor investigation was a proof-of-concept study directed at determining the design factors necessary for the development of a full-scale system, while the much larger pilot-scale system evaluation was directed at developing guidance information for full-scale WWTP operational parameters.

We conducted this project jointly with the Oro Loma Sanitary District (OLSD) using their San Lorenzo WWTP that serves the Alameda County, California and the surrounding communities. This WWTP processes about 57,000 $\mathrm{m}^{3} /$ day (15 Mgal/day) of mainstream sewage and generates an AD filtrate side-stream of $\sim 418 \mathrm{~m}^{3} /$ day $(110,000$ gal/day). As this is an operational plant for the District, the primary project goal was to reduce the side-stream $\mathrm{AD}$ filtrate nitrogen concentrations (ranging from 300 to $700 \mathrm{mg} \mathrm{NH}-\mathrm{N} / \mathrm{L}$ ) to $\mathrm{NH}_{3}-\mathrm{N}$ and $\mathrm{NO}_{3}-\mathrm{N}$ concentrations of $<100 \mathrm{mg} / \mathrm{L}$. Achieving such a reduction in the AD filtrate ammonia concentration and returning the treated filtrate to the primary or secondary clarifiers would reduce the overall nitrogen loading in the WWTP treatment train. We based our work in part on the laboratory observations of Mansell [6] and Kotay et al. [8], who deployed a partial-nitritation dual-tank anammox reactor to treat AD filtrate that has a similar concept to the zeolite-anammox reactor. They reported a degradation factor or a removal rate of about 
$300 \mathrm{~g} \mathrm{~N} / \mathrm{m}^{3} /$ day, more than enough to achieve the OLSD project discharge goals. However, their reactor had a long retention time of $>200$ days in a controlled laboratory setting and we hoped to improve on that with much shorter retention times while functioning in an actual WWTP environment.

AD side-streams may have very high Total Suspended Solids (TSS) levels formed from recalcitrant substances that pass through the digester and behave as inert solids that inevitably lead to clogging problems in downstream operations. As zeolite media is essentially a fixed-bed film reactor, the aggregate particle sizes are chosen to accommodate biofilm growth while enabling sufficient transmissivity that is not prone to clogging. Thus, we also sought to determine when clogging occurs and what approaches might ameliorate clogging effects and keep treatment reactors in service. Additional study objectives included the consideration of the anammox (bio-zeolite) seeding rates required to develop an operational and sustainable zeolite-anammox treatment system in a reasonable period (i.e., weeks), and the evaluation of the effects of aerobic-anaerobic cycling within the reactor on ammonia removal rates. As with previous efforts, this project also aimed to lower treatment costs at the OLSD WWTP while still achieving or improving the discharge water quality.

\section{Methodology}

We first developed individual $210 \mathrm{~L}$ barrel reactors for proof-of-concept treatment studies of the AD filtrate. Secondly, we created a $\sim 68-\mathrm{m}^{3}$ (18,000 gal) intermediate-scale 'Baker tank' reactor designed to treat $10 \%$ of the WWTP AD filtrate and again examined the start-up time and aerobic-anaerobic operation effects on ammonia-N removal rates. We used readily available zeolite ( $97 \%$ pure clinoptilolite) from Nevada in both reactors (see properties in Table 1) and 'seeded' both with 'bio-zeolite' (zeolite aggregate coated with anammox and nitrifier bacterial biofilms) at $10 \%$ by volume in the barrel reactors and at about $1.5 \%$ by volume in the Baker tank. Microbial analyses by the UC Davis Genome Center of the bulk liquid samples from the bio-zeolite incubator used metagenomic shotgun Illumina sequencing to examine the microbial community present in the samples. Briefly, sequences were assembled with MegaHit ( $\mathrm{Li}$ et al. [9]), reads were mapped back to the assembly with Bowtie 2 (Langmead and Salzburg [10]), and taxonomy was assigned to the sequences with Kaiju (Menzel et al. [11]). For the completely submerged biozeolite (anaerobic), known anammox bacteria comprised about $30 \%$ of the identified sequences, while in cyclically submerged biozeolite (partially aerobic), anammox bacteria comprised about $15 \%$ of the identified sequences. All of these sequences belong to the Candidatus Brocadiaceae family that contains several species of anammox bacteria. We reported similar results on the presence of anammox bacteria in our zeolite-anammox reactors previously (Collison and Grismer [1]).

Influent to both the barrel and Baker tank reactors was obtained from $3.4 \mathrm{~m}^{3}$ (1000 gal) and $30 \mathrm{~m}^{3}$ (8000 gal) AD filtrate storage-settling tanks, respectively. Both reactors were designed as recirculating trickling-filter reactors and operated as two-layer aerobic-anaerobic treatment systems to take advantage of the nitritation-anammox process described by Zekker et al. [12] and the oxycline described in our review (Grismer and Collison [7]). In effect, the two-layer zeolite-anammox system within a single reactor enables the top layer to produce nitrite (equivalent to the Sharon process in a separate tank) while, presumably, a combination of denitrifying and anammox bacteria in the lower submerged layer converts nitrite and ammonia to nitrogen gas.

As schematically shown in Figure 1, the barrel $(0.54 \mathrm{~m}$ diam $\times 0.92 \mathrm{~m}$ tall) reactors had matching pipe manifolds at the top and bottom of each barrel that either supplied AD filtrate to a sprinkler-head assembly centered over the top (upper manifold) or collected drainage from the barrel base (lower manifold). Zeolite aggregate $(10$ or $20 \mathrm{~mm}$ ) was loaded into each barrel to a depth of about $0.8 \mathrm{~m}$, and after settling due to transport, had a dry bulk density of about $900 \mathrm{~kg} / \mathrm{m}^{3}$. Each barrel reactor included a recirculating pump that took collected water from the barrel base and returned it to the sprinkler at the top of the reactor with a roughly 8-h recycle period. Automated valves at the inlet, discharge and pump enabled control of inflow, recirculation, and discharge each day resulting in an overall hydraulic retention time of $23-24 \mathrm{~h}$ at an average flow rate of $4.0 \mathrm{~L} / \mathrm{h}$. The AD 
filtrate influent to each barrel reactor maintained the reactor operating temperature at about $20{ }^{\circ} \mathrm{C}$. The aerobic-anaerobic treatment occurred by maintaining the water surface elevation at approximately two-thirds of the barrel aggregate height to form the anaerobic layer while the top third was the trickling-filter 'aerated' system.

Table 1. Zeolite properties—High purity (97\%) clinoptilolite from Amargosa Valley, Nevada.

\begin{tabular}{cc}
\hline Property & Value \\
\hline Cation Exchange Capacity (CEC) & $1.6-2.0 \mathrm{meq} / \mathrm{g}$ \\
Particle Density & $1890 \mathrm{~kg} / \mathrm{m}^{3}$ \\
Specific Surface & $40 \mathrm{~m}^{2} / \mathrm{g}$ \\
Internal pore size & $0.4-0.7 \mathrm{~nm}$ \\
Hardness & $4-5.0 \mathrm{Mohs}$ \\
\hline
\end{tabular}

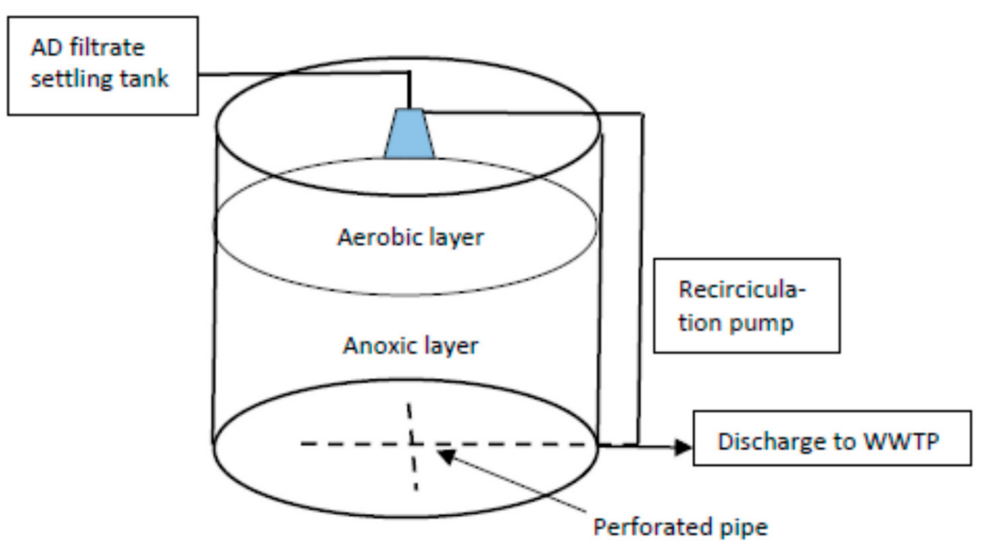

Figure 1. The schematic of the $210 \mathrm{~L}$ barrel reactor.

We used these smaller barrel reactors to determine the time required for anammox bacteria activity to obtain a $\sim 80 \%$ ammonia removal and that time required before TSS clogging limited the reactor treatment performance. We anticipated that the smaller $(10 \mathrm{~mm})$ zeolite aggregate reactor would clog more quickly than the $20 \mathrm{~mm}$ aggregate reactor, but that it could achieve greater nitrogen removal rates per unit volume. When clogging became apparent in the barrels with the decrease of the flow, we attempted to clear the clogging by backflushing each barrel by forcing high-pressure water into the outlet port with limited success. We conducted the pilot-scale barrel reactor testing for approximately four months, sampling barrel influent and effluent every 1-2 weeks from December 2013 to March 2014.

Following the proof-of-concept study using the barrel reactors, we built an intermediate-scale Baker tank reactor designed to treat approximately $41.6 \mathrm{~m}^{3} /$ day (11,000 gal/day) of the AD filtrate. As schematically illustrated in Figure 2, the Baker tank reactor was approximately $9 \mathrm{~m}$ long by $2.5 \mathrm{~m}$ wide by $3.0 \mathrm{~m}$ deep and filled with the same $20-\mathrm{mm}$ zeolite aggregate used in the barrel reactors through six access holes created at the top of the container. Without aggregate settling as in the barrels, we estimated that there was a smaller aggregate bulk density of $\sim 850 \mathrm{~kg} / \mathrm{m}^{3}$ in the Baker tank. A movable sprayer assembly operated over the top of the aggregates, and like the barrel reactors, a recirculation pump enabled control of the water level in the tank to create an aerobic trickling-filter type top meter layer and a submerged anaerobic layer about $2 \mathrm{~m}$ thick $\left(\sim 45 \mathrm{~m}^{3}\right)$. Automated control valves at the inlet, outlet, and pump enabled daily cyclic inflow and recirculation resulting in a design hydraulic retention time of 21-22 h. The Baker tank experiments included two sequential operational stages during a 15-month period from July 2014 to October 2015. During the July 2014 to March 2015 first stage, the Baker tank reactor operated as a trickling-filter similar to that used in the barrel study prior to significant aggregate clogging. Clogging and fluctuating tank water levels affected the 
second stage performance period of the Baker tank, but provided insight into the aeration effects on the zeolite-anammox system performance.

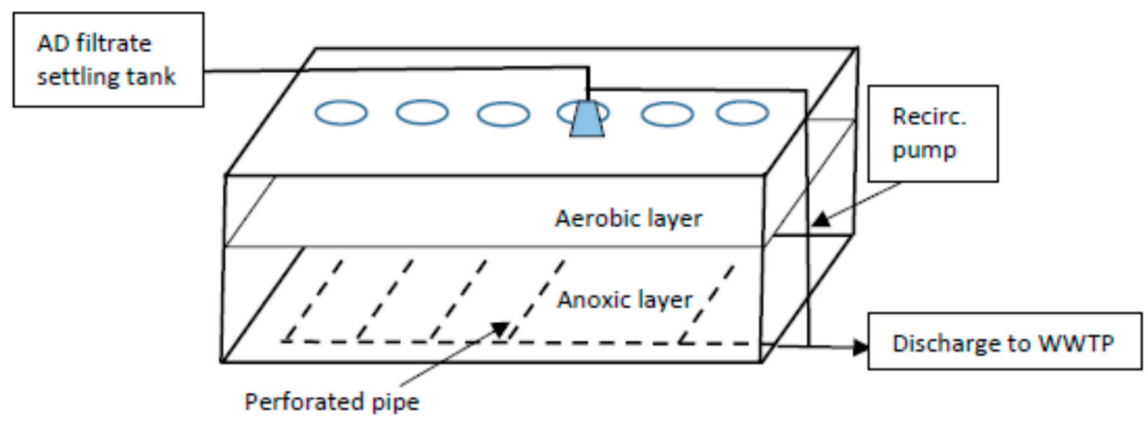

Figure 2. The schematic of the Baker tank reactor.

Water quality analyses of wastewater samples were conducted within the OLSD lab as needed for regulatory compliance as well as through Alpha Analytical Laboratories (California NELAP Certified) using standard quality assurance procedures that included blank, chemical standard and replicate samples with each run of sample analyses for a particular constituent. Table 2 summarizes the analytical methods used for the analysis of each constituent. From limited periodic sampling during the study period, the AD filtrate TSS concentration was highly variable and averaged $1600 \mathrm{mg} / \mathrm{L}$ while the AD filtrate BOD concentrations averaged $<35 \mathrm{mg} / \mathrm{L}$. Temporary storage of the AD effluent in the settling tanks upstream of the reactors provided limited TSS removal by gravity settling and we found that the WWTP operator procedures had a significant effect on the influent TSS concentrations to the Baker tank. Influent nitrite concentrations were $<0.1 \mathrm{mg} / \mathrm{L}$ and nearly all nitrogen existed as ammonia. Where applicable we used the two-tailed Student's t-distribution to test for statistical significance in comparisons of constituent mean values resulting from different operations because of the small numbers $(\sim 10)$ of samples from which means were determined.

Table 2. The analytical methods used for water quality analyses.

\begin{tabular}{cc}
\hline Analyte & Method \\
\hline Alkalinity & Standard Methods 2320B \\
Biological Oxygen Demand (BOD) & EPA 405.1 \\
$\mathrm{NO}_{3}-\mathrm{N}$ & EPA 300.0/9056 \\
$\mathrm{NH}_{3}-\mathrm{N}$ & Standard Methods 4500-NH3D \\
Total Suspended Solids (TSS) & Standard Methods 2540D \\
\hline
\end{tabular}

\section{Results and Discussion}

\subsection{Barrel Reactors}

Analysis of the changing effluent ammonia- and nitrate- $\mathrm{N}$ concentrations from the barrel reactors study enabled the assessment of the time required for the anammox bacteria to become fully functional in terms of ammonia removal while also gaining insight into the effects of the zeolite particle size on the 'maturation' process and the likely clogging problems associated with AD filtrate TSS loading. Both the large and small zeolite aggregate barrel reactors reached treatment goals of $\sim 80 \%$ nitrogen removal (i.e., $<100 \mathrm{mg} \mathrm{NH}_{3}-\mathrm{N} / \mathrm{L}$ ) within 6-8 weeks of operation when the apparent anammox colonization of the reactor was sufficient for nitrate removal. This period was much shorter than the 26 weeks required for maturation of the linear-channel reactors described earlier (Collison and Grismer [1]). Notwithstanding the problems of wastewater iron deficiency (Collison and Grismer [1]), we surmise that this greater start-up time was because the linear-channel reactor was seeded at only $3 \%$ by volume rather than $10 \%$ and fed much smaller influent ammonia-N concentrations of $\sim 35 \mathrm{mg} / \mathrm{L}$ (as compared to $\sim 500 \mathrm{mg} / \mathrm{L}$ here). 
Summarized in Table 3 are the weekly influent and outlet ammonia- and nitrate-N concentrations for the small- and large-aggregate barrel reactors during the last 12 weeks of the 15-week study. A variety of management and pumping problems at the WWTP and the associated lab resulted in questionable sampling during the first two weeks of the study. During weeks 3-5 of the study, effluent nitrate increased rapidly as nitrifying bacteria oxidized influent ammonia and likely stripped adsorbed ammonia from the zeolite. In the next two weeks (weeks 5-7), effluent nitrate decreased rapidly as anammox activity in the reactor increased consuming the available nitrite and combining it with ammonia to form nitrogen gas. Finally, after 7-9 weeks effluent ammonia and nitrate-N concentrations stabilized and we presume that the system reached an apparent balance of bacterial communities and achieved treatment discharge goals of nitrogen species concentrations $<100 \mathrm{mg} / \mathrm{L}$. Though the overall treatment performances associated with each aggregate size were similar, the smaller-aggregate barrel reactor demonstrated a slightly better overall ammonia removal rates during weeks $7-15$ with an average outlet concentration of $66 \mathrm{mg} \mathrm{NH} 3-\mathrm{N} / \mathrm{L}$ as compared to $88 \mathrm{mg} \mathrm{NH}_{3}-\mathrm{N} / \mathrm{L}$ for the larger-aggregate reactor. While the two outlet mean ammonia concentrations differed significantly at the $95 \%$ confidence level and the larger zeolite aggregate system had a slightly lower performance with respect to ammonia (or nitrate) removal, it was far less prone to clogging by the large TSS load of the AD filtrate.

During the latter 5 weeks, the barrel trickling-filter reactor removed about $400 \mathrm{mg} \mathrm{NH}_{3}-\mathrm{N} / \mathrm{L}$ on average, or a degradation factor of $290 \mathrm{~g} / \mathrm{m}^{3}$ submerged media/day. This latter degradation value was consistent with the $300 \mathrm{~g} / \mathrm{m}^{3} /$ day reported by Mansell [6] for a solution-type anammox reactor on the same bulk volume basis, though here only one reactor container is used and it is full of aggregate.

As we described previously for the linear-channel zeolite-anammox reactors (Collison and Grismer [1]), we believe that the anammox bacteria are significantly active in the barrel reactors after the first roughly 8 weeks because;

1. assuming ammonium ions displace all other cations on the zeolite exchange sites, the sites would be ammonium saturated in about the first 9 days of operation, far less than the $>100$ days of operation,

2. the reactors achieved ammonia-N removal rates approaching the theoretical value from the anammox reaction stoichiometry (Strous et al. [13]), and

3. the available carbon source concentrations (i.e., $\sim 35 \mathrm{mg} \mathrm{BOD} / \mathrm{L}$ ) in the $\mathrm{AD}$ filtrate were only sufficient for the removal of $\sim 9 \mathrm{mg} / \mathrm{L}$ by denitrification on average (Metcalf and Eddy [14]) of the $400 \mathrm{mg} / \mathrm{L}$ ammonia actually removed.

Table 3. The influent and outlet ammonia and nitrate concentrations in barrel zeolite-anammox reactors during the 15-week study period.

\begin{tabular}{|c|c|c|c|c|c|c|c|}
\hline \multirow{2}{*}{$\begin{array}{l}\text { Weeks of } \\
\text { Operation }\end{array}$} & \multirow{2}{*}{$\begin{array}{c}\text { Influent } \mathrm{NH}_{3}-\mathrm{N} \\
\text { Conc. }(\mathrm{mg} / \mathrm{L})\end{array}$} & \multicolumn{3}{|c|}{ Outlet-10 mm Aggregate } & \multicolumn{3}{|c|}{ Outlet-20 mm Aggregate } \\
\hline & & $\begin{array}{c}\mathrm{NH}_{3}-\mathrm{N} \\
(\mathrm{mg} / \mathrm{L})\end{array}$ & $\begin{array}{l}\mathrm{NO}_{3}-\mathrm{N} \\
(\mathrm{mg} / \mathrm{L})\end{array}$ & $\begin{array}{c}\mathrm{NH}_{3}-\mathrm{N} \\
\text { Removal (\%) }\end{array}$ & $\begin{array}{l}\mathrm{NH}_{3}-\mathrm{N} \\
(\mathrm{mg} / \mathrm{L})\end{array}$ & $\begin{array}{c}\mathrm{NO}_{3}-\mathrm{N} \\
(\mathrm{mg} / \mathrm{L})\end{array}$ & $\begin{array}{c}\mathrm{NH}_{3}-\mathrm{N} \\
\text { Removal (\%) }\end{array}$ \\
\hline 4 & 502 & 28 & 541 & 94.4 & 29 & 338 & 94.2 \\
\hline 5 & 500 & 36 & 826 & 92.8 & 34 & 334 & 93.2 \\
\hline 7 & 523 & 31 & 101 & 94.1 & 57 & 147 & 89.1 \\
\hline 10 & 488 & 78 & 71 & 84.0 & 103 & 116 & 78.9 \\
\hline 11 & 481 & 81 & 72 & 83.2 & 91 & 131 & 81.1 \\
\hline 12 & 465 & 63 & 136 & 86.5 & 66 & 124 & 85.8 \\
\hline 13 & 495 & 68 & 105 & 86.3 & 91 & 108 & 81.6 \\
\hline 14 & 484 & 84 & 91 & 82.6 & 110 & 92 & 77.3 \\
\hline
\end{tabular}




\subsection{Baker Tank Reactor-First Stage Operating as Designed}

Following successful treatment using the barrel reactors, we built the intermediate-scale Baker tank reactor to both cultivate bio-zeolite as well as to treat $10 \%$ of the WWTP side-stream AD filtrate flows. The tank's design considered some of the issues encountered in the barrel reactor studies at the larger scale, but was subject to several practical limitations that included;

1. little available bio-zeolite aggregate for reactor seeding,

2. a likely disruption of the aggregate biofilms while loading the tank,

3. an inadequate AD filtrate TSS pretreatment prior to entering the Baker tank, and

4. an associated lack of back-flushing capacity.

After filling, we initially covered the Baker tank access holes with plywood to limit sunlight and rainfall access to the surface layer. Later, removal of the plywood covers by the WWTP staff allowed direct sunlight onto the media surface within the tank. The sunlight promoted algal growth, forming a composite mat of algae, suspended solids, and bacterial floc that reduced the influent infiltration through the media. At times, sprinkled influent sheet flowed across the top of the mat moving almost directly (i.e., 'short-circuiting') down the sidewalls to the effluent discharge pipe with little treatment. As the WWTP required a continuous operation, we used this period of partial mat coverage as an opportunity to operate the Baker tank as a flood-drain or cycling system rather than a static anaerobic-aerobic system, recognizing that we were uncertain of the reactor volume actively participating in the treatment. Later, after removing the near impervious algal mat and some of the surface TSS-clogged media, we partially restored the Baker tank to its designed operation with the $1 \mathrm{~m}$ thick deep trickling-filter layer overlaying a $2 \mathrm{~m}$ thick submerged (anaerobic) layer. We consider the nitrogen removal performance of the Baker tank reactor under each of these two sequential stages of aerobic-anaerobic conditions.

Based on the effluent monitoring as described with the barrel reactors above, the Baker tank reactor achieved an $\sim 80 \%$ ammonia- $\mathrm{N}$ removal after about one year. This long start-up period was likely a result of the very small seeding rate (1.5\% bio-zeolite by volume) possible in the tank. Table 4 summarizes the monitoring results from the first stage of the Baker tank reactor during the latter 8-months (July 2014 to March 2015) of the first-year study period. During this test period, the tank water temperatures varied from $20-25^{\circ} \mathrm{C}$ depending on the season while the tank influent $\mathrm{pH}$ averaged 7.1 at an alkalinity of about $1600 \mathrm{mg} / \mathrm{L}$ and the tank effluent $\mathrm{pH}$ averaged 7.6 with an alkalinity of about $550 \mathrm{mg} / \mathrm{L}$ and TSS concentration of about $120 \mathrm{mg} / \mathrm{L}$. Influent nitrogen and TSS concentrations were quite variable during this sampling period and, as with the barrel reactors, based on the changing effluent ammonia- and nitrate- $\mathrm{N}$ concentrations, the nitrifying bacteria quickly established themselves while anammox bacteria established more slowly. The tank effluent nitrate-N concentration peaked after about 150 days and then fell below $50 \mathrm{mg} / \mathrm{L}$ after 239 days, indicating an eventual anammox activity. Overall, the average effluent ammonia- and nitrate-N concentrations were below the WWTP project goal of $<100 \mathrm{mg} / \mathrm{L}$, or $80 \%$ ammonia removal during the 239 -day period.

Table 4. The inlet and outlet ammonia and nitrate concentrations during the first stage Baker tank reactor operation as a two-layer, aerobic-anaerobic recirculating trickling-filter system.

\begin{tabular}{ccccc}
\hline Stage $\mathbf{1}$ Days & $\begin{array}{c}\text { Influent } \mathbf{N H}_{\mathbf{3}}-\mathbf{N} \\
(\mathbf{m g} / \mathbf{L})\end{array}$ & $\begin{array}{c}\text { Effluent } \mathbf{N H}_{\mathbf{3}}-\mathbf{N} \\
(\mathbf{m g} / \mathbf{L})\end{array}$ & $\begin{array}{c}\text { Effluent } \mathbf{N O}_{\mathbf{3}}-\mathbf{N} \\
(\mathbf{m g} / \mathbf{L})\end{array}$ & $\begin{array}{c}\mathbf{N H}_{\mathbf{3}}-\mathbf{N} \text { Removal } \\
(\mathbf{\%})\end{array}$ \\
\hline 1 & 420 & 12 & 0.1 & 97.1 \\
11 & 380 & 27 & 0.9 & 92.9 \\
25 & 510 & 50 & 0.1 & 90.2 \\
39 & 510 & 83 & 0.1 & 83.7 \\
42 & 530 & 69 & 13 & 87.0 \\
57 & 450 & 59 & 71 & 86.9 \\
\hline
\end{tabular}


Table 4. Cont.

\begin{tabular}{ccccc}
\hline Stage 1 Days & $\begin{array}{c}\text { Influent } \mathbf{N H}_{\mathbf{3}}-\mathbf{N} \\
(\mathbf{m g} / \mathbf{L})\end{array}$ & $\begin{array}{c}\text { Effluent } \mathbf{N H}_{\mathbf{3}}-\mathbf{N} \\
(\mathbf{m g} / \mathbf{L})\end{array}$ & $\begin{array}{c}\text { Effluent } \mathbf{N O}_{\mathbf{3}}-\mathbf{N} \\
(\mathbf{m g} / \mathbf{L})\end{array}$ & $\begin{array}{c}\mathbf{N H}_{\mathbf{3}}-\mathbf{N} \text { Removal } \\
(\mathbf{\%})\end{array}$ \\
\hline 71 & 300 & 70 & 110 & 76.7 \\
85 & 520 & 220 & 170 & 57.7 \\
99 & 300 & 90 & 55 & 70.0 \\
113 & 490 & 76 & 130 & 84.5 \\
127 & 460 & 80 & 170 & 82.6 \\
141 & 540 & 95 & 87 & 82.4 \\
153 & 520 & 110 & 260 & 78.8 \\
169 & 360 & 99 & 140 & 72.5 \\
183 & 460 & 100 & 190 & 78.3 \\
197 & 250 & 100 & 59 & 60.0 \\
211 & 590 & 50 & 160 & 91.5 \\
225 & 370 & 130 & 61 & 64.9 \\
239 & 710 & 95 & 49 & 86.6 \\
\hline
\end{tabular}

Despite slightly increasing and variable inlet ammonia concentrations during the last six weeks of monitoring when the anammox bacteria were likely actively involved in treatment, the average inlet and outlet $\mathrm{NH}_{3}-\mathrm{N}$ concentrations were about 457 and $96 \mathrm{mg} / \mathrm{L}$ for a removal efficiency of about $79 \%$. Using the submerged reactor volume (residence time of $\sim 0.9$ days), the aerobic-anaerobic trickling-filter operation of the tank reactor removed about $340 \mathrm{~g} \mathrm{NH}_{3}-\mathrm{N} / \mathrm{m}^{3} /$ day, somewhat greater than that achieved in the barrel reactors $\left(290 \mathrm{~g} / \mathrm{m}^{3} /\right.$ day) but consistent with $300 \mathrm{~g} / \mathrm{m}^{3} /$ day reported by Mansell [6] and Kotay et al. [8] for their partial nitration-anammox laboratory reactor. Both removal rates are about an order-of-magnitude greater than that achieved (21-42 $\mathrm{g} \mathrm{NH}_{3}-\mathrm{N} / \mathrm{m}^{3}$ total media/day) in the linear-channel flow reactor treating low-ammonia strength secondary effluent due to the order-of-magnitude greater influent ammonia concentrations of the AD filtrate and lower operating temperatures (Collison and Grismer [1]).

\subsection{Baker Tank Reactor-Second Stage Operation with Clogged Media}

After the first 8 months of the Baker tank reactor operation, localized aggregate clogging affected the surface flows across the top of the zeolite media during the next three months (April to June 2015), resulting in limited AD filtrate treatment. Clogging problems were not immediately apparent because they were only observable when the recirculating trickling-filter sprinkler heads were flowing and the WWTP staff were on top of the tank watching. About this same time, problems with the recirculation pump automation (timer) resulted in tank water levels varying somewhere between as low as $0.3 \mathrm{~m}$ and the design level of $2 \mathrm{~m}$. Figure 3 illustrates the reactor influent and effluent nitrogen concentrations during this period and the curve periodicity reflects the cyclic variation in the submerged layer thickness within the tank as fluctuating nitrate concentrations. The average ammonia concentration of the tank reactor effluent during this 3-month period was $182 \mathrm{mg} / \mathrm{L}$, while the nitrate concentrations averaged $67 \mathrm{mg} / \mathrm{L}$. Generally, because of the flow short-circuiting and increased aeration associated with the flood-drain cycling within the tank, the average ammonia-N removal fraction of the Baker tank declined to $\sim 62 \%$ but it achieved a greater nitrate removal. This decrease in removal rates was the combined effect of aggregate pore clogging, decreased flow access to the entire media volume, and the associated smaller effective residence time for treatment. 


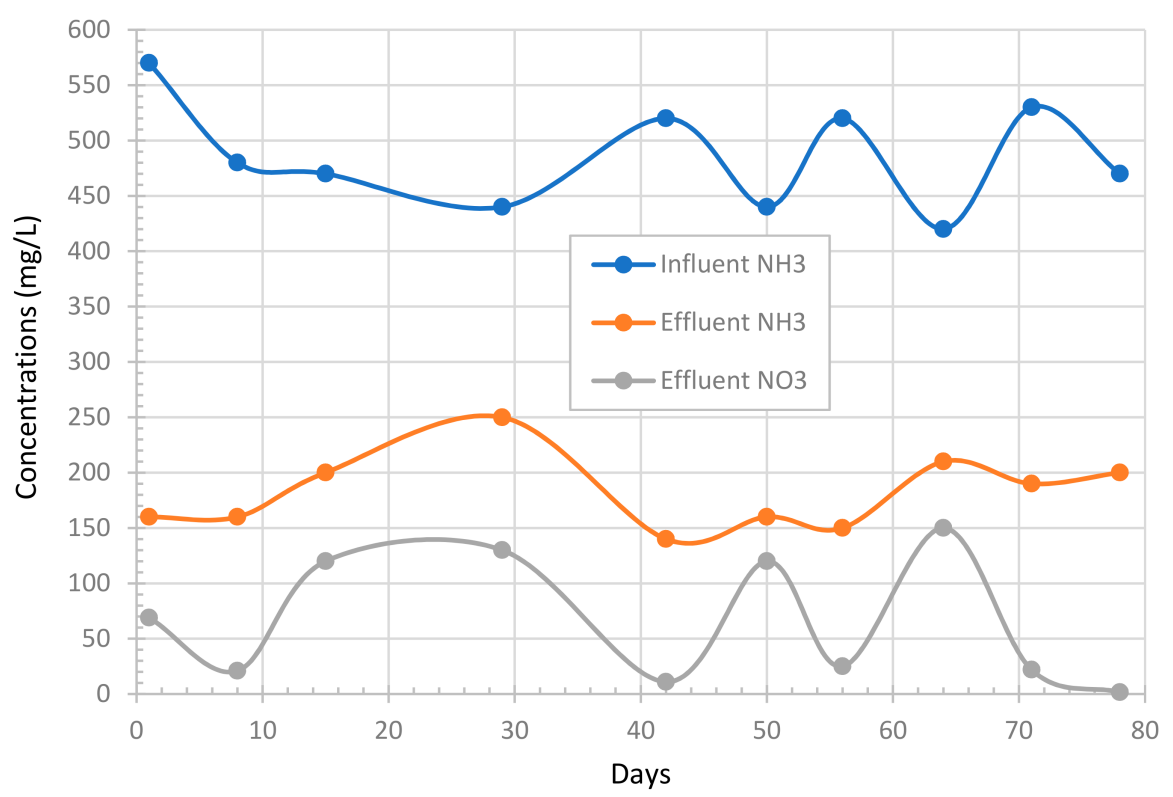

Figure 3. The Baker tank-reactor effluent ammonia and nitrate concentrations during the first part of the second-stage test period when surface clogging and flood-drain cycling occurred.

At the end of June, we removed much of the algal suspended solids surface mat as well as some of the TSS clogged zones in the Baker tank reactor using a Vactor truck that partially restored the reactor to its original designed operation. The previous flood-drain cycling likely promoted a stratified biofilm comprised of nitrifying bacteria overlaying anammox bacteria on the zeolite surfaces. Monitoring results from this second part of the second stage of the Baker tank reactor study (July-October 2015) are summarized in Table 5. During this period, the partial pore clogging of the top aerated media layer reduced the vertical flowrates into the submerged layer of the reactor. Decreased aeration of the lower layer increased the anammox bacterial growth below and initially impaired the ammonia oxidation by nitrifiers due to the decreased oxygen availability. Despite anoxic conditions in this lower layer, an inadequate organic food supply (i.e., BOD concentrations $<35 \mathrm{mg} / \mathrm{L}$ ) limited the denitrifying bacterial growth indicating that nitrate removal by such bacteria was insignificant in this layer. Rather, the absence of nitrate and excess ammonia likely promoted the dissimilatory nitrate reduction to ammonium (DNRA) by anammox bacteria such as $K$. stuttgartiensis and the near complete nitrogen removal such that effluent nitrate- $\mathrm{N}$ concentrations were consistently $\sim 0.1 \mathrm{mg} / \mathrm{L}$. Gradually increasing influent ammonia-N concentrations during the last 6 weeks of this second stage test period resulted in gradually increasing effluent ammonia-N concentrations, though the nitrate-N concentrations remained $<1 \mathrm{mg} / \mathrm{L}$.

Table 5. The Baker tank reactor nitrogen monitoring results during the second stage operation as a nitrate scavenging system and bio-zeolite cultivator.

\begin{tabular}{ccccc}
\hline Stage 2 Days & $\begin{array}{c}\text { Influent } \mathbf{N H}_{\mathbf{3}}-\mathbf{N} \\
(\mathbf{m g} / \mathbf{L})\end{array}$ & $\begin{array}{c}\text { Effluent } \mathbf{N H}_{\mathbf{3}}-\mathbf{N} \\
(\mathbf{m g} / \mathbf{L})\end{array}$ & $\begin{array}{c}\text { Effluent } \mathbf{N O}_{\mathbf{3}}-\mathbf{N} \\
(\mathbf{m g} / \mathbf{L})\end{array}$ & $\begin{array}{c}\mathbf{N H}_{\mathbf{3}}-\mathbf{N} \text { Removal } \\
(\mathbf{\%})\end{array}$ \\
\hline 1 & 490 & 200 & 3.1 & 59.2 \\
8 & 460 & 150 & 1.0 & 67.4 \\
15 & 480 & 180 & 0.1 & 62.5 \\
22 & 510 & 230 & 0.1 & 54.9 \\
29 & 370 & 210 & 1.6 & 43.2 \\
36 & 420 & 200 & 0.1 & 52.4 \\
43 & 470 & 220 & 0.1 & 53.2 \\
50 & 430 & 250 & 0.1 & 41.9 \\
57 & 420 & 300 & 0.1 & 28.6 \\
\hline
\end{tabular}


Table 5. Cont.

\begin{tabular}{|c|c|c|c|c|}
\hline Stage 2 Days & $\begin{array}{c}\text { Influent } \mathrm{NH}_{3}-\mathrm{N} \\
(\mathrm{mg} / \mathrm{L})\end{array}$ & $\begin{array}{l}\text { Effluent } \mathrm{NH}_{3}-\mathrm{N} \\
(\mathrm{mg} / \mathrm{L})\end{array}$ & $\begin{array}{c}\text { Effluent } \mathrm{NO}_{3}-\mathrm{N} \\
(\mathrm{mg} / \mathrm{L})\end{array}$ & $\begin{array}{c}\mathrm{NH}_{3}-\mathrm{N} \text { Removal } \\
(\%)\end{array}$ \\
\hline 64 & 420 & 280 & 0.5 & 33.3 \\
\hline 71 & 420 & 280 & 1.0 & 33.3 \\
\hline 78 & 620 & 260 & 0.1 & 58.1 \\
\hline 85 & 500 & 310 & 0.1 & 38.0 \\
\hline 99 & 520 & 320 & 0.4 & 38.5 \\
\hline 106 & 640 & 350 & 1.9 & 45.3 \\
\hline Means & 478 & 249 & 0.7 & 47.3 \\
\hline
\end{tabular}

With the continued influent flow rate of about $41 \mathrm{~m}^{3} /$ day and the partial media clogging that resulted in a decreased aeration from the trickling-filter layer, the average ammonia-N removal fraction dropped to about $47 \%$ on average. Thus, the Baker tank became an excellent bio-zeolite cultivation chamber for seeding future reactors. On the other hand, we believe that the stratified biofilm of nitrifying bacteria overlaying anammox bacteria on the zeolite aggregate led to a very efficient nitrite capture by anammox bacteria that maintained an effluent nitrate concentration of $<1 \mathrm{mg} / \mathrm{L}$. Overall, ammonia and nitrate removal rates from the $\mathrm{AD}$ filtrate during this second-stage test period were about $210 \mathrm{~g} \mathrm{NH}_{3}-\mathrm{N} / \mathrm{m}^{3} /$ day and $430 \mathrm{~g} \mathrm{NO}_{3}-\mathrm{N} / \mathrm{m}^{3} /$ day, respectively, assuming a submerged volume of $45 \mathrm{~m}^{3}$ as originally designed.

Though it became clear that the partial gravitational settling in the storage tanks prior to the influent sprinkling was insufficient to prevent TSS clogging of the upper aggregate materials in either the barrel or Baker tank reactors, budgetary constraints at the WWTP precluded additional pre-treatment to remove excess TSS from the AD filtrate. After 18 months of operation, an additional $7.6 \mathrm{~m}^{3}$ (2000 gal) of the conical-clarifier tank was placed inline after the $30 \mathrm{~m}^{3}$ tank to reduce the influent TSS to the Baker tank, but overall gravity settling was never fully effective. Overall, the Baker tank reactor successfully removed ammonia from the AD filtrate to levels desired by the WWTP during a nearly one-year period at a fraction of the cost of other treatment options considered. However, without pretreatment reduction of the high TSS content of the AD filtrate and/or the development of an adequate back-flushing capability within the tank reactors, long-term sustained ammonia removal from the AD filtrate is unlikely due to aggregate media pore clogging. On the other hand, we found that the operation of the Baker tank reactor as an anaerobic system enabled the near complete removal of nitrate from the AD filtrate and the successful cultivation of bio-zeolite for use as seeding materials in other reactors. We are exploring the further application of this discovery to other WWTP systems.

\section{Summary and Conclusions}

Water quality concerns in the San Francisco Bay-Delta associated with WWTPs discharge has led to several efforts to find cost-effective methods for reducing the nitrogen content of wastewater in many of the WWTP operations. In this second paper, considering the upscaling of the zeolite-anammox nitrogen removal process to commercial applications, we investigated the treatment of relatively high-ammonia content ( $\left.\sim 500 \mathrm{NH}_{3}-\mathrm{N} \mathrm{mg} / \mathrm{L}\right)$ anaerobic-digester (AD) filtrate to a discharge project goal of $<100 \mathrm{mg} / \mathrm{L}$. Using $210 \mathrm{~L}$ barrel reactors operated as layered trickling-filter systems, we first explored the time required for seeded anammox bacteria to establish and become operational and if the system could successfully treat the AD filtrate. We found that at a seeding fraction of $10 \%$ by volume, about seven weeks were required before the anammox bacterial treatment became apparent as decreased nitrate concentrations in the barrel reactor effluent. In these same barrel reactors, we found that the smaller zeolite aggregate $(10 \mathrm{~mm})$ as compared to larger aggregate $(20 \mathrm{~mm})$ achieved a statistically significant $(p<0.05)$ greater ammonia removal fraction $(89 \%$ vs. $85 \%)$ and that both met the goal effluent concentrations. However, the use of the smaller aggregate resulted in greater pore-clogging problems during the 15-week test period. 
Next, we upscaled the successful barrel reactor trickling-filter design to a $\sim 68 \mathrm{~m}^{3}$ Baker tank filled with the $20 \mathrm{~mm}$ aggregate and first operated it as a trickling-filter aerated-anaerobic layered reactor and later, following clogging and pump problems, as a bio-zeolite cultivator. We anticipated likely clogging problems associated with the high TSS loading of the AD filtrate in the tank reactor and operated the tank reactor until the clogging effects on the treatment performance became apparent. Nonetheless, the tank reactor also achieved acceptable effluent $\mathrm{NH}_{3}-\mathrm{N}$ and $\mathrm{NO}_{3}-\mathrm{N}$ concentrations averaging 85 and $91 \mathrm{mg} / \mathrm{L}$, respectively, during the 8-month first-stage period prior to aggregate clogging and the formation of a composite mat on the media surface. With the tank aggregate surface covered or clogged, we examined the effects of surface flow short-circuiting and aerobic-anaerobic cycling within the tank on treatment performance and found that cycling aerobic conditions or the thickness of the submerged layer could be associated with fluctuating effluent nitrate concentrations.

Following the partial restoration of aggregate surface materials in the second stage of the tank reactor study, we took advantage of the apparent layered bacterial biofilms (nitrifier over anammox bacteria on the zeolite aggregate) obtained from the prior flood-drain cycling to examine the nitrate scavenging potential of the zeolite-anammox reactor. As others using anammox reactors have noted (Mansell [6]; Grismer and Collison [7]), we found that the continuous submergence of the zeolite media in the tank favored anammox growth over nitrifiers, while the lack of a carbon source limited the growth of denitrifiers, likely promoting the DRNA reactions while efficiently cultivating bio-zeolite for use in seeding other zeolite-anammox reactors. Encouraging the apparent anammox DRNA reactions provided interesting results and has important ramifications for treating wastewaters subject to both ammonium and total nitrogen (TN) discharge limits.

The generally accepted anammox stoichiometric equation (Strous et al. [13]) indicates that each mole of ammonium consumed releases about 0.26 moles of nitrate. Thus, the theoretical maximum possible TN removal is about $74 \%$ by 'typical' anammox bacteria. Anammox bacteria (e.g., K. stuttgartiensis) using the DNRA process, however, could conceivably achieve a nearly $100 \% \mathrm{TN}$ removal, as observed during the second stage of the tank reactor study that had a consistent effluent nitrate- $\mathrm{N}$ concentration of $<0.1 \mathrm{mg} / \mathrm{L}$ even with the large nitrogen loading. We note that for DNRA to occur in the zeolite-anammox system, wastewater containing excess ammonia in conjunction with negligible nitrite is required (anoxic conditions) and that while the available nitrate was removed, the effluent contained untreated ammonia as was found towards the end of our study. During this stage having a partially-aerated clogged upper layer and fully anaerobic lower layer, nitrate effluent concentrations were $<1 \mathrm{mg} / \mathrm{L}$ underscoring this capacity of the anammox bacteria in removing nitrogen, but ammonia removal fractions were only about $47 \%$. Consequently, it becomes important to balance ammonia and nitrite/nitrate concentrations within the system carefully to achieve very low effluent TN concentrations.

Overall, by using submerged reactor volumes, we determined ammonia-N removal rates of $290 \mathrm{~g} \mathrm{NH}_{3}-\mathrm{N} / \mathrm{m}^{3}$ / day in the barrel reactors and roughly 340 and $210 \mathrm{~g} \mathrm{NH}_{3}-\mathrm{N} / \mathrm{m}^{3} /$ day, respectively, in the tank reactor when operated as designed, and when partially restored with a preponderance of anammox bacteria in the submerged layer, perhaps enabling the DNRA removal of nitrate. These compare well with that of $\sim 300 \mathrm{~g} \mathrm{~N} / \mathrm{m}^{3}$ /day from a partial-nitration-anammox laboratory reactor described by Mansell [6]. Future upscaling of the processes described here for the successful treatment of the OLSD AD filtrate side stream requires the pretreatment of filtrate recalcitrant TSS concentrations, the inclusion of effective backflushing mechanisms within the large tank reactors, or more likely, a combination of both processes. From a practical perspective, we learned that WWTP management of a single large tank reactor is problematic and that we could likely obtain the same treatment performed using a parallel series of smaller tank reactors. With multiple smaller tank reactors, individual tanks requiring maintenance or having problems (e.g., clogging, pumps) can be taken off-line, serviced, and returned to operation without compromising the treatment performance of the overall system. We consider such a multiple-tank treatment system in a future paper. 
Author Contributions: This was a joint effort by the authors who both conceptualized the project design that was carried out by R.S.C. R.S.C. worked with OLSD staff at the Treatment Plant to collect and analyze samples and prepare preliminary results. M.E.G. completed the analysis and drafted the paper for publication.

Funding: No outside grant support.

Acknowledgments: This project was supported by the operators and staff of the Oro Loma Sanitary District (OLSD) San Lorenzo Wastewater Treatment Plant, without whom this work could not have been completed.

Conflicts of Interest: The authors declare no conflicts of interest.

\section{References}

1. Collison, R.S.; Grismer, M.E. Upscaling the Zeolite-Anammox process: Treatment of secondary effluent. Water 2018, 10, 236. [CrossRef]

2. San Francisco Estuary Institute (SFEI). San Francisco Bay Nutrient Management Strategy Science Plan; Richmond, CA, USA, 2016; Available online: http:/ / sfbaynutrients.sfei.org/sites/default/files/2016_NMSSciencePlan_ Report_Sep2016.pdf (accessed on 31 October 2018).

3. Lackner, S.; Terada, A.; Smets, B.F. Heterotrophic activity compromises autotrophic nitrogen removal in membrane-aerated biofilms: Results of a modeling study. Water Res. 2008, 42, 1102-1112. [CrossRef] [PubMed]

4. Dapena-Mora, A.; Campos, J.L.; Mosquera-Corral, A.; Jetten, M.S.; Méndez, R. Stability of the ANAMMOX process in a gas-lift reactor and a SBR. J. Biotechnol. 2004, 110, 159-170. [CrossRef] [PubMed]

5. Collison, R.S.; Grismer, M.E. Nitrogen and Chemical Oxygen Demand removal from septic tank wastewater in subsurface flow constructed wetlands: Substrate (Cation Exchange Capacity) effects. Water Environ. Res. 2014, 86, 314-323. [CrossRef] [PubMed]

6. Mansell, B.L. Side-Stream Treatment of Anaerobic Digester Filtrate by Anaerobic Ammonia Oxidation. Master's Thesis, University of Utah, Salt Lake City, UT, USA, May 2011.

7. Grismer, M.E.; Collison, R.S. The Zeolite-Anammox wastewater treatment process-A review. Water 2017, 9, 901. [CrossRef]

8. Kotay, S.M.; Mansell, B.L.; Hogsett, M.; Pei, H.; Goel, R. Anaerobic ammonia oxidation (ANAMMOX) for side-stream treatment of anaerobic digester filtrate process performance and microbiology. Biotechnol. Bioeng. 2013, 110, 1180-1192. [CrossRef] [PubMed]

9. Li, D.; Liu, C.M.; Luo, R.; Sadakane, K.; Lam, T.W. MEGAHIT: An ultra-fast single-node solution for large and complex metagenomics assembly via succinct de Bruijn graph. Bioinformatics 2015, 31, 1674-1676. [CrossRef] [PubMed]

10. Langmead, B.; Salzberg, S.L. Fast gapped-read alignment with Bowtie 2. Nat. Methods 2012, 9, 357-359. [CrossRef] [PubMed]

11. Menzel, P.; Ng, K.L.; Krogh, A. Fast and sensitive taxonomic classification for metagenomics with Kaiju. Nat. Commun. 2016, 7, 11257. [CrossRef] [PubMed]

12. Zekker, I.; Rikmann, E.; Tenno, T.; Saluste, A.; Tomingas, M.; Menert, A.; Loorits, L.; Lemmiksoo, V.; Tenno, T. Achieving nitritation and anammox enrichment in a single moving-bed biofilm reactor treating reject water. Environ. Technol. 2012, 33, 703-710. [CrossRef] [PubMed]

13. Strous, M.; Heijnen, J.J.; Kuenen, J.G.; Jetten, M.S.M. The sequencing batch reactor as a powerful tool for the study of slowly growing anaerobic ammonium oxidizing microorganisms. Appl. Microbiol. Biotechnol. 1998, 50, 589-596. [CrossRef]

14. Metcalf and Eddy, Inc. Wastewater Engineering: Treatment, Disposal and Reuse, 3rd ed.; Tchobanoglous, G., Burton, F., Eds.; McGraw-Hill, Inc.: New York, NY, USA, 1991.

(c) 2018 by the authors. Licensee MDPI, Basel, Switzerland. This article is an open access article distributed under the terms and conditions of the Creative Commons Attribution (CC BY) license (http:/ / creativecommons.org/licenses/by/4.0/). 